\title{
ANALYSIS OF NITRATE, PHOSPHATE AND SILICATE CONTENT AND THEIR EFFECTS ON PLANKTONIC ABUNDANCE IN THE ESTUARY WATERS OF BATANG ARAU OR PADANG CITY WEST SUMATRA PROVINCE
}

\author{
Weni Indah Wahyuni ${ }^{1}$, Bintal Amin ${ }^{1}$, Sofyan Husein Siregar ${ }^{1}$ \\ ${ }^{1}$ Department of Marine Science, Faculty of Fisheries and Marine Universitas Riau, Pekanbaru \\ *weniindah96@gmail.com
}

\begin{abstract}
The entry of nutrients (nitrate, phosphate and silicate) from land-based anthropogenic activities (industry, agriculture and household waste) through rivers can potentially cause changes in water quality and will affect fertility and aquatic organisms such as phytoplankton. These three nutrients play an important role in the living tissue cells of living organisms and in the photosynthesis process. This study aims to analyze the effect of nitrate, phosphate and silicate content on the plankton abundance in the estuary of the Batang Arau River, Padang, West Sumatra. The method used is a survey method, the determination of the sampling station is done by purposive sampling, data were analysed by Excel and SPSS Software. Based on the results of laboratory analysis, the nitrate content ranged from 0,117 to $0,485 \mathrm{mg} / \mathrm{l}$, phosphate content from 0,239 to $0,704 \mathrm{mg} / \mathrm{l}$, and silicate content from 0,031 to $0,685 \mathrm{mg} / \mathrm{l}$. Planktonic diatom abundance in the estuary of the Batang Arau River ranges from 194 to $750 \mathrm{ind} / \mathrm{l}$. The results of the statistical analysis of the effect of nitrate, phosphate and silicate with an abundance of diatoms are expressed by the equation $\mathrm{Y}=743,019$ 481,828 Nitrate $-199,552_{\text {Phosphate }}-172,971_{\text {Silicate }}$. This equation explains that the effect of nitrate, phosphate and silicate content on diatom abundance has an inverse or negative relationship, where nitrate, phosphate and silicate levels increase, the diatom abundance will decrease. The difference of content and the relationship between parameters analyzed in this research are discussed.
\end{abstract}

Keywords: Nitrate, Phosphate, Silicate, Diatom, West Sumatra.

\section{PENDAHULUAN}

Senyawa nitrat, fosfat dan silikat secara alamiah berasal dari perairan itu sendiri melalui proses-proses penguraian, pelapukan ataupun dekomposisi tumbuhtumbuhan, sisa-sisa organisme mati dan buangan limbah baik limbah daratan seperti domestik, industri, pertanian, dan limbah peternakan ataupun sisa pakan yang dengan adanya bakteri terurai menjadi zat hara [1] Hal ini akan memberi pengaruh terhadap tingginya kandungan unsur hara yang masuk ke perairan. Akibatnya pencemaran unsur hara organik dan anorganik menjadi tidak terkendali. Masuknya nutrien yang berasal dari daratan melalui sungai akan mempengaruhi kesuburan perairan dimana nutrien merupakan zat yang dapat mempengaruhi dan dibutuhkan oleh organisme perairan seperti fitoplankton, terutama nitrat fosfat, dan silikat. Ketiga nutrien ini berperan penting terhadap sel jaringan jasad hidup organisme serta dalam proses fotosintesis. 
Diatom merupakan fitoplankton yang banyak dijumpai di perairan laut yang berperan sebagai produser primer, sebagai sumber makanan bagi organisme lain, dan mampu merubah bahan anorganik menjadi organik, sehingga dalam rantai makanan di perairan laut menempati tropik level pertama [2]. Selain itu, diatom adalah salah satu kelompok besar fitoplankton yang banyak menarik perhatian untuk diteliti karena keberadaannya yang selalu mendominasi di wilayah perairan laut dibandingkan dengan komunitas mikroalga lainnya.

Perairan Muara Sungai Batang Arau merupakan salah satu perairan yang berada di Kota Padang, Sumatera Barat. Padatnya aktivitas penduduk di sepanjang aliran muara sungai ini membuat pemanfaatannya pun cukup beragam, seperti sebagai tempat buangan terutama buangan sampah rumah tangga, limbah domestik, pertanian, industri, rumah sakit, pelabuhan kapalkapal nelayan dan kapal penumpang serta sebagai daerah rekreasi terutama sejak dibangun Jembatan Siti Nurbaya. Hal ini menyebabkan terjadinya penurunan kualitas perairan dalam waktu jangka panjang. Padatnya aktivitas penduduk di sepanjang aliran muara sungai menyebabkan perairan ini rentan akan pencemaran yang berasal dari berbagai sumber seperti limbah industri, pertanian, transportasi laut, dan limbah domestik.

Limbah dari aktivitas penduduk ini baik itu limbah organik maupun limbah anorganik dapat mengubah kadar nutrien di perairan, seperti nitrat, fosfat, dan silikat. Perlu diketahui perairan tidak hanya dimanfaatkan oleh manusia saja, melainkan biota laut yang hidup diperairan tersebut, diantaranya diatom. Beberapa spesies diatom sensitif terhadap perubahan lingkungan sehingga dapat menggambarkan perubahan lingkungan dalam periode yang pendek dan jangka panjang. Senyawa nitrat, fosfat, silikat merupakan faktor kunci menentukan kesuburan perairan juga merupakan unsur yang sangat dibutuhkan untuk tumbuh dan berkembangnya diatom.

Tujuan Penelitian ini adalah untuk mengetahui kandungan nitrat, fosfat, dan silikat serta kelimpahan diatom planktonik dan menganalisis pengaruh kandungan nitrat, fosfat, dan silikat terhadap kelimpahan diatom planktonik di Perairan Muara Sungai Batang Arau, Padang Sumatera Barat.

\section{METODE PENELITIAN Waktu dan Tempat}

Penelitian ini telah dilaksanakan pada bulan Oktober 2019 di Perairan Muara Sungai Batang Arau, Kota Padang, Provinsi Sumatera Barat. Sampel untuk kandungan nitrat, fosfat, dan silikat dianalisis di Laboratorium Kimia Laut Fakultas Perikanan dan Kelautan, sedangkan sampel diatom dianalisis di Laboratorium Biologi Laut Fakultas Perikanan dan Kelautan, Universitas Riau.

\section{Metode Penelitian}

Metode yang digunakan dalam penelitian ini adalah metode survei yaitu dengan melakukan pengamatan dan pengambilan sampel secara langsung di lapangan. Penentuan stasiun penelitian dilakukan secara purposive sampling, yaitu pengambilan sampel pada stasun penelitian diambil berdasarkan karakteristik lingkungan perairan yang berbeda dengan beberapa pertimbangan yang dianggap sesuai dengan tujuan penelitian. Maka stasiun penelitian dibagi atas 5 (lima) stasiun (Gambar 1).

a. Stasiun I terletak di aliran Muara Sungai Batang Arau yang merupakan daerah padat penduduk dan aktivitas perkapalan.

b. Stasiun II berada di mulut Muara Sungai Batang Arau dan berdekatan dengan darmaga tempat berlabuhnya kapal-kapal nelayan dan kapal penumpang dengan rute pelayaran Padang-Mentawai. 
c. Stasiun III-V terletak di di bagian kiri dan kanan Muara Sungai Batang Arau

yang berbatasan langsung dan menghadap ke arah laut.

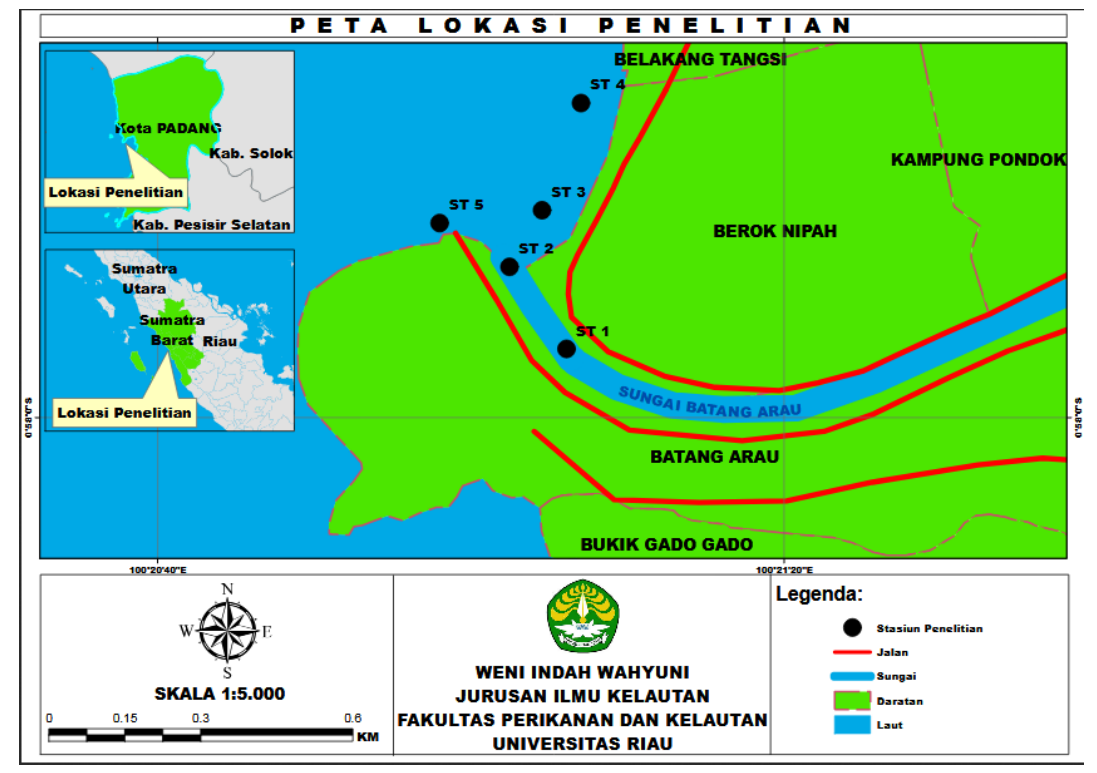

Gambar 1. Peta Stasiun Penelitian

\section{Prosedur Penelitian \\ Pengambilan Sampel}

Pengambilan sampel air untuk nitrat, fosfat, dan silikat dilakukan pada waktu siang hari bersamaan dengan pengambilan sampel diatom yaitu dengan menggunakan ember plastik yang diambil di permukaan perairan. Kemudian sampel tersebut dimasukkan ke dalam botol sampel yang telah diberi label keterangan (stasiun dan titik sampling). Untuk pengawetan sampel nitrat ditambahkan larutan asam sulfat pekat hingga $\mathrm{pH} 2$, sedangkan untuk sampel fosfat dan silikat tidak diberikan pengawet. Selanjutnya botol botol sampel tersebut dibungkus dengan menggunakan alumunium foil dan dimasukkan ke dalam icebox untuk menjaga keawetan sampel sampai ke Laboratorium.

Pengambilan sampel diatom dilakukan pada waktu siang hari antara pukul 11.00 - 15.00 WIB. Sampel diatom diambil pada daerah permukaan sebanyak 100 liter menggunakan ember berukuran 10 liter yang sudah di standarisasi terlebih dahulu, kemudian disaring menggunakan planktonnet No.25. Hasil penyaringan sebanyak $125 \mathrm{ml}$ dimasukkan ke dalam botol sampel dan diberi pengawet berupa lugol $4 \%$ sebanyak 4 tetes, selanjutnya diberi label dan diamati di laboratorium.

\section{Pengukuran Kualitas Air}

Pengukuran kualitas perairan diukur bersamaan dengan pengambilan sampel nitrat, fosfat, dan silikat serta diatom. Pengukuran kualitas perairan diukur sebanyak 3 kali pengulangan. Parameter kualitas air yang diukur adalah kecerahan, suhu, oksigen terlarut, salinitas, kecepatan arus dan $\mathrm{pH}$.

Pengukuran nitrat, fosfat dan silikat dilakukan dengan mengacu pada metode [3].

\section{Pengukuran Kelimpahan Diatom}

Pengukuran kelimpahan diatom dilakukan sebagai berikut:

1. Sampel yang telah diambil diaduk rata, kemudian diambil dengan menggunakan pipet tetes, diteteskan pada object glass dan ditutup dengan cover glass, kemudian diamati di bawah mikroskop.

2. Pengamatan diatom dilakukan dengan metode sapuan, dengan mengamati 
semua kolom di object glass dengan perbesaran 10 x 10 sebanyak 3 kali pengulangan pada masing-masing sampel.

3. Selanjutnya jenis diatom dari kelas Bacillarophyceae yang terlihat diidentifikasi dengan menggunakan buku identifikasi [4], kemudian jenis diatom yang ditemukan didokumentasikan.

4. Setelah itu jenis diatom yang sama dikelompokkan dan dihitung kelimpahannya.

Kelimpahan diatom dihitung dengan menggunakan metode sapuan merujuk pada rumus [5] sebagai berikut:

Keterangan:

$$
\text { Jumlah sel/liter } N=\frac{X}{Y} \times \frac{1}{V} \times Z
$$

$$
\begin{aligned}
\mathrm{N}= & \text { Kelimpahan fitoplankton (ind/liter) } \\
\mathrm{X}= & \text { Volume air yang tersaring }(125 \mathrm{ml}) \\
\mathrm{Y}= & \text { Volume air sampel di bawah cover } \\
& \text { glass }(0,06 \mathrm{ml}) \\
\mathrm{V}= & \text { Volume air sampel yang disaring } \\
& \begin{array}{l}
\text { (100 liter) } \\
\mathrm{Z}=
\end{array} \\
& \text { Jumlah individu yang ditemukan } \\
& \text { (ind) }
\end{aligned}
$$

\section{Analisis Data}

Analisis secara statistik menggunakan ANOVA satu arah (One Way Anova) untuk mengetahui perbedaan antar stasiun dari kandungan nitrat, fosfat, dan silikat. Analisis regresi berganda digunakan untuk mengetahui besarnya pengaruh kandungan nitrat, fosfat dan silikat terhadap kelimpahan diatom. persamaan regresi linear berganda sebagai berikut:

$$
Y^{\prime}=a+b_{1} X_{1}+b_{2} X_{2}+\ldots . .+b_{n} X_{n}
$$

Keterangan:

$$
\begin{aligned}
\mathrm{Y}^{\prime} & \text { Kelimpahan diatom (sel/l) } \\
\mathrm{X}_{1} \text { dan } \mathrm{X}_{\mathrm{n}}= & \text { Nitrat, fosfat, silikat } \\
\mathrm{a} & \text { Konstanta } \\
\mathrm{b} & \begin{array}{l}
\text { Koefisien regresi (nilai } \\
\text { peningkatan ataupun } \\
\text { penurunan). }
\end{array}
\end{aligned}
$$

\section{HASIL DAN PEMBAHASAN Kondisi Umum}

Perairan Muara Sungai Batang Arau terletak di Kelurahan Batang Arau, Kecamatan Padang Selatan, Kota Padang, Provinsi Sumatera Barat yang berada pada koordinat $0^{\circ} 57^{\prime} 47^{\prime \prime}$ LS dan $100^{\circ} 21^{\prime} 03^{\prime \prime}$ BT. Perairan Muara Sungai Batang Arau merupakan Daerah Aliran Sungai (DAS). DAS Batang Arau terdiri dari beberapa anak sungai dan sungai utamanya adalah Sungai Batang Arau. Sumber air DAS Batang Arau berasal dari hulu DAS pada kawasan pegunungan Bukit Barisan di sebelah timur kota Padang dan bermuara di Samudera Indonesia. Hulu DAS Batang Arau dimulai dari sungai Lubuk Paraku yang berada di Timur Laut Kota Padang, dengan daerah tangkapan air seluas 2.504 hektar yang merupakan Taman Hutan Raya Dr. Muhammad Hatta, Kawasan Suaka Alam Barisan I dan Arau Hilir [6].

Dinas Lingkungan Hidup (DLH) Kota Padang menyatakan Sungai Batang Arau merupakan sungai yang paling tercemar di daerah ini, dibandingkan empat sungai besar lainnya. Sebab Sungai Batang Arau menjadi tempat pembuangan limbah dari hulu sampai hilir. Kepala Dinas Lingkungan Hidup Kota Padang Mairizon mengungkap, dimulai dari hulu sungai Batang Arau, ada pembuangan clay dari pabrik semen, kemudian ada pabrik sawit dan pabrik karet. Lanjut ke bagian tengah, ada rumah sakit dan klinik kecil. Kemudian dibagian hilir ada pembuangan limbah Pasar Raya, dan kondisi diperparah oleh kapal yang bersandar di Muara juga membuang sampah dan limbah langsung ke sungai Batang Arau akibatnya pencemaran unsur hara organik dan anorganik menjadi tidak terkendali.

\section{Parameter Kualitas Perairan}

Hasil pengukuran parameter kualitas perairan pada setiap stasiun penelitian diketahui bahwa suhu di Perairan Muara Sungai Batang Arau berkisar antara 30- 
$32^{\circ} \mathrm{C}$, kecerahan berkisar antara $0,45-1,8 \mathrm{~m}$, kecepatan arus berkisar 0,16-0,31 m/det, $\mathrm{pH}$ berkisar antara 5-7, salinitas berkisar antara 7-35 ppt, dan oksigen terlarut berkisar 4,53-8 mg/l (Tabel 1).

Tabel 1. Parameter Kualitas Perairan

\begin{tabular}{lccccc}
\hline \multicolumn{1}{c}{ Parameter } & Stasiun I & Stasiun II & Stasiun III & Stasiun IV & Stasiun V \\
\hline Suhu $\left({ }^{\circ} \mathrm{C}\right)$ & 31 & 31 & 31 & 30 & 32 \\
Kecerahan $(\mathrm{m})$ & 0,45 & 0,5 & 1,5 & 1,6 & 1,8 \\
Kecepatan Arus $(\mathrm{m} / \mathrm{s})$ & 0,31 & 0,31 & 0,23 & 0,16 & 0,19 \\
pH & 5 & 6 & 7 & 6 & 6 \\
Salinitas (ppt) & 7 & 7 & 30 & 30 & 35 \\
DO (mg/l) & 4,53 & 6 & 6,8 & 7,3 & 8 \\
\hline
\end{tabular}

\section{Kandungan Nitrat, Fosfat dan Silikat di Perairan Muara Sungai Batang Arau}

Kandungan nitrat yang tertinggi terdapat pada pada Stasiun I dengan ratarata $0,485 \mathrm{mg} / \mathrm{l}$ (Gambar 2), tingginya nilai kandungan nitrat pada stasiun ini dibandingkan dengan stasiun lainnya dikarenakan stasiun ini berada di kawasan pemukiman padat penduduk yang mendapat masukan limbah domestik secara terus menerus. Menurut [7] bahwa tingginya konsentrasi zat hara nitrat di perairan dapat disebabkan tingginya pengaruh daratan yang banyak mensuplai zat organik dari limbah antropogenik seperti aktivitas rumah tangga, permukiman, pertanian dan peternakan. Hal serupa juga di ungkapkan oleh [8-9] menyatakan bahwa kadar nitrat di perairan dekat pantai cenderung tinggi akibat adanya tambahan dari daratan melalui sungai-sungai. Sedangkan kandungan nitrat terendah terdapat pada Stasiun V dengan rata-rata $0,117 \mathrm{mg} / \mathrm{l}$, rendahnya kandungan nitrat di stasiun ini diduga karena sumber masukan suplai nutrien nitrat sudah semakin sedikit dan jaraknya yang jauh dari pemukiman penduduk dan semakin dekat ke arah laut sehingga nilai kandungan nitrat semakin mendekat kearah laut akan semakin menurun dan pola sebaran konsentrasi nitrat semakin ke arah laut lepas maka konsentrasi nitrat akan semakin rendah. Hal ini sesuai dengan pendapat [10] menyatakan bahwa estuari merupakan salah satu sumber nutrien di laut. Wilayah muara memiliki konsentrasi nutrien lebih tinggi dan konsentrasi nutrien tersebut akan menurun menuju laut lepas. Perbedaan kandungan nitrat dari pemukiman hingga laut lepas pantai mengalami penurunan disebabkan karena perbedaan kuantitas buangan limbah di lingkungan masing-masing stasiun. Menurut [11], distribusi nitrat antara muara dengan laut lepas bervariasi dimana dekat pantai lebih tinggi dibanding lokasi jauh dari pantai.

Kandungan fosfat tertinggi terdapat pada Stasiun I dengan nilai $0,704 \mathrm{mg} / \mathrm{l}$, tingginya kandungan fosfat pada stasiun I dapat disebabkan karena area tersebut berada pada kawasan padat penduduk yang mensuplai limbah dari kegiatan antrophogenik dan area ini lebih dangkal yang merupakan daerah pencampuran massa air secara langsung. Menurut [12] tingginya kadar fosfat disebabkan arus dan pengadukan massa air yang mengakibatkan terangkatnya kandungan fosfat yang tinggi dari dasar ke lapisan permukaan. Hal ini juga dikemukakan oleh [7], bahwa fenomena ini lumrah terjadi karena dasar perairan selalu kaya akan zat hara, selain berasal dari dasar perairan itu sendiri, juga dari sumbangan dekomposisi detritus dan buangan limbah domestik rumah tangga. Kandungan fosfat yang tinggi pada Stasiun I juga diduga adanya pengaruh dari daratan melalui sungai sungai dan pembuangan 
sampah organik maupun anorganik yang dibuang langsung keperairan laut oleh penduduk sekitar. Seperti yang diungkapkan oleh [13] bahwa fosfat dapat bersumber dari limbah rumah tangga, limbah industri (obat-obatan dan tekstil), peternakan, limbah pertanian, proses mineralisasi dan pembebasan nutrisi pada sedimen yang masuk ke badan air. Sedangkan kandungan fosfat terendah terdapat pada Stasiun V dengan nilai 0,239 $\mathrm{mg} / \mathrm{l}$, rendahnya kandungan fosfat pada stasiun ini karena area tersebut jauh dari daratan. Kandungan fosfat umumnya semakin menurun jauh ke arah laut [14].

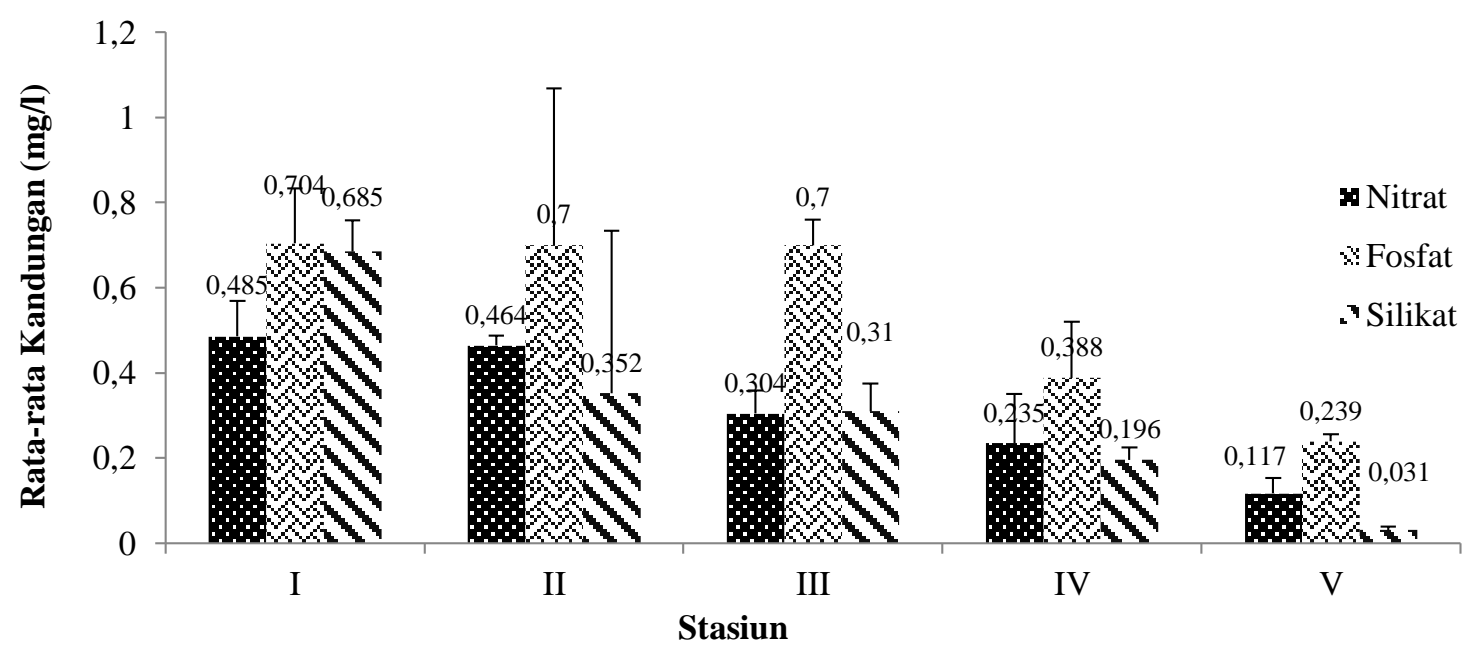

Gambar 2. Kandungan Nitrat, Fosfat dan Silikat (Rata-rata \pm St.Dev)

Kandungan silikat tertinggi terdapat pada Stasiun I dengan nilai $0,685 \mathrm{mg} / \mathrm{l}$, tingginya kandungan silikat pada stasiun ini disebabkan oleh pengaruh aktifitas penduduk yang dibuang ke perairan laut dan lokasi yang dekat dengan muara sungai yang merupakan tempat akumulasi buangan limbah daratan [15], sedangkan kandungan silikat terendah terdapat pada Stasiun V dengan nilai $0,031 \mathrm{mg} / \mathrm{l}$, rendahnya kandungan silikat pada stasiun ini dikarenakan pemasukan dari daratan terbatas sehingga perairan ini memiliki kadar silikat lebih rendah. [16] menyatakan bahwa distribusi silikat di perairan pesisir umumnya lebih tinggi dari pada di laut terbuka. Menurut [17] sumber utama kandungan silikat dalam suatu perairan banyak dipengaruhi proses erosi serta curah hujan. Nutrien silikat diperlukan dan berpengaruh terhadap proses pertumbuhan dan perkembangan hidup beberapa organisme.
Hasil uji anova satu arah untuk kandungan nitrat, fosfat, dan silikat diperoleh nilai signifikasi berturut-turut yaitu $0,000,0,031,0,012$ sehingga $\mathrm{P}<0,05$ yang menandakan kandungan nitrat, fosfat, dan silikat antar stasiun penelitian berbeda nyata.

\section{Diatom Planktonik di Perairan Muara Sungai Batang Arau}

Menurut [18] klasifikasi diatom dibagi dalam 2 tipe, yaitu Centrales diatom yang mempunyai bentuk radial simetri. Centrales terlihat dari atas (valve view) berbentuk lingkaran kadang segitiga dan Pennales diatom yang mempunyai bentuk bilateral simetri, Pennales terlihat dari atas dapat berbentuk garis, lancet, elip atau ovoid.

Dari hasil pengamatan diperoleh 20 spesies diatom planktonik dari keseluruhan titik sampling pada kelima stasiun yang dapat dilihat pada Tabel 2 . 
Tabel 2. Klasifikasi Diatom Planktonik di Perairan Muara Batang Arau

\begin{tabular}{|c|c|c|c|c|c|}
\hline No. & Tipe & Kelas & Ordo & Family & Spesies \\
\hline 1 & Centrales & Bacillariophyceae & Biddulphiales & Biddulphiaceae & Isthmia $\mathrm{sp}$ \\
\hline 2 & & & Cosinodiscophycidae & Melosirales & Melosira $\mathrm{sp}$ \\
\hline 3 & & & Leptocylindrales & Leptocylindraceae & Leptocylindrus $\mathrm{sp}$ \\
\hline 4 & & & Cosinodiscales & Cosinodiscaceae & Cosinodiscus sp \\
\hline 5 & & & Centroles & Chaetoceraceae & Chaetoceros sp \\
\hline 6 & & & Biddulphiales & Biddulphiaceae & Tricertium $\mathrm{sp}$ \\
\hline 7 & & & Chaetocerles & Chaetocerotaceae & Bacteriastrum $\mathrm{sp}$ \\
\hline 8 & & & Thalassiosirales & Stephanodiscaceae & Cyclotela $\mathrm{sp}$ \\
\hline 9 & & & Rhizosoleniales & Rhizosoleniaceae & Rhizosolenia sp \\
\hline 10 & Pennales & Bacillariophyceae & Bacillariales & Bacillariaceae & Nitzchia sp \\
\hline 11 & & & Naviculales & Naviculaceae & Navicula $\mathrm{sp}$ \\
\hline 12 & & & Cymbellales & Cymbellaceae & Cymbella $\mathrm{sp}$ \\
\hline 13 & & & Fragilariales & Fragilariaceae & Synedra sp \\
\hline 14 & & & Thalassionematales & Thalassionemata & Thalassionema $\mathrm{sp}$ \\
\hline 15 & & & Bacillariales & Bacillariaceae & Bacillaria sp \\
\hline 16 & & & Achnanthales & Achnantaceae & Achnantes sp \\
\hline 17 & & & Naviculales & Neidiaceae & Neidium sp \\
\hline 18 & & & Biddulphiales & Biddulphiceae & Biddulphia sp \\
\hline 19 & & & Naviculales & Stauroneidaceae & Craticula $\mathrm{sp}$ \\
\hline 20 & & & Naviculales & Diploneidaceae & Diploneis sp \\
\hline
\end{tabular}

Tabel 2 dapat diketahui bahwa diatom yang ditemui di Perairan Muara Sungai Batang Arau yaitu sebanyak 20 spesies, dimana 9 spesies tergolong ke dalam tipe diatom Centrales diantaranya Isthmia sp, Melosira sp, Leptocylindrus sp, Cosinodiscus sp, Chaetoceros sp, Tricertium sp, Bacteriastrum sp, Cyclotela sp dan Rhizosolenia sp. dan 11 spesies diatom lainnya tergolong ke dalam diatom tipe Pennales, adapun diantaranya yaitu Nitzchia sp, Navicula sp, Cymbella sp, Synedra sp, Thalassionema sp, Bacillaria $\mathrm{sp}$, Achnantes sp, Neidium sp, Biddulphia sp, Craticula sp dan Diploneis sp.

\section{Kelimpahan Diatom Planktonik di Perairan Muara Sungai Batang Arau}

Diatom merupakan organisme yang digunakan sebagai bioindikator pada kualitas perairan dari organisme/kelompok organisme lainnya. Keunggulan tersebut antara lain: distribusi sangat luas, populasinya bervariasi, mempunyai peranan yang penting di dalam rantai makanan, dijumpai pada hampir semua permukaan substrat sehingga mampu merekam sejarah habitatnya, siklus hidup pendek, cepat bereproduksi, banyak dari anggota spesiesnya yang sensitif terhadap perubahan lingkungan sehingga cepat meresponnya, mampu merefleksikan perubahan-perubahan kualitas air baik dalam jangka pendek maupun jangka panjang [19].

Kelimpahan diatom di suatu perairan selalu berubah seiring dengan perubahanperubahan yang terjadi di lingkungan sekitarnya. Kelimpahan diatom planktonik yang ditemukan di Perairan Muara Sungai Batang Arau memiliki nilai bervariasi (Gambar 3).

Nilai rata-rata kelimpahan diatom planktonik tertinggi terdapat pada Stasiun $\mathrm{V}$ yang nilai 750 ind/l, dimana stasiun penelitian ini berbatasan dan langsung menghadap ke arah laut. Pada stasiun ini kondisi kualitas perairannya baik seperti kecerahan, dimana perairan dalam kondisi jernih sehingga memungkinkan penetrasi 
cahaya matahari secara optimal masuk ke dalam perairan yang kemudian digunakan diatom untuk berfotosintesis.

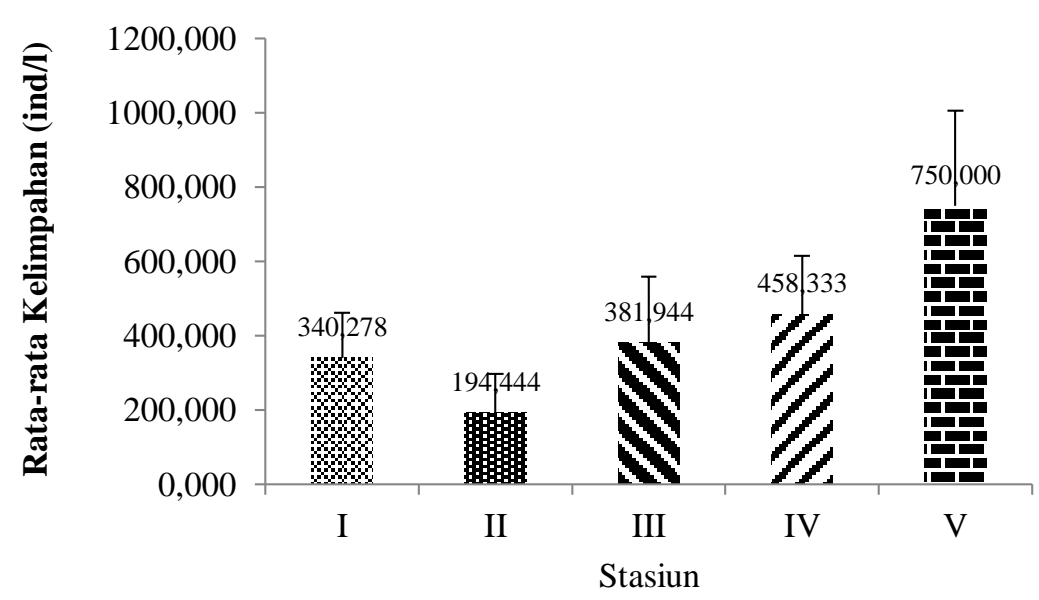

Gambar 3. Kelimpahan Diatom Planktonik (Rata-rata \pm St.Dev)

Tingginya kelimpahan diatom pada Stasiun V karena dipengaruhi oleh kualitas perairan yang baik. Menurut [20] kecerahan adalah suatu ukuran untuk mengetahui daya penetrasi matahari ke dalam air. Semakin tinggi nilai kecerahan semakin tinggi nilai kelimpahan diatom. Hal ini sesuai dengan pendapat [21] bahwa kecerahan air merupakan ukuran kejernihan di suatu perairan, semakin tinggi suatu kecerahan perairan semakin dalam cahaya matahari menembus ke dalam air. Keberadaan cahaya sangat mempengaruhi pertumbuhan diatom sebagai produsen primer di perairan laut. Cahaya matahari berfungsi sebagai sumber energi yang digunakan oleh diatom untuk berfotosintesis, pertumbuhan, produktivitas, dan mempengaruhi sebaran diatom pada perairan laut. Berkurangnya kecerahan air akan mengurangi kemampuan fotosintesis tumbuhan air, selain itu juga mempengaruhi kegiatan fisiologi biota air, dalam hal ini bahanbahan ke dalam suatu perairan terutama yang berupa suspensi dapat mengurangi kecerahan air.

Nilai rata-rata kecerahan pada Stasiun $\mathrm{V}$ adalah nilai kecerahan tertinggi pada stasiun penelitian dari pada stasiun lainnya yaitu senilai $1,8 \mathrm{~m}$. Menurut [22], nilai kecerahan yang baik untuk kehidupan organisme adalah lebih besar dari $0,45 \mathrm{~m}$ sehingga penetrasi dan absorbsi di perairan tersebut akan berlangsung optimal.

Kelimpahan diatom terendah terdapat pada Stasiun II yaitu 194 ind/l, dimana stasiun ini berada dekat dengan mulut Muara Sungai Batang Arau dan berdekatan dengan dermaga tempat berlabuhnya kapalkapal nelayan dan kapal penumpang dengan rute pelayaran Padang-Mentawai. Hal ini akan memberi pengaruh terhadap kualitas perairan di sekitar stasiun ini, dimana dengan adanya kegiatan perkapalan diduga akan menghasilkan limbah minyak yang berasal dari tangki bahan bakar kapal. Limbah minyak yang langsung masuk ke perairan akan membuat sebuah lapisan pada permukaan perairan. Akibatnya cahaya matahari yang masuk ke perairan akan terhalang dan difusi oksigen dari udara ke dalam air akan berkurang. Sehingga mempengaruhi pertumbuhan organisme air termasuk diatom.

Rendahnya kelimpahan pada stasiun II ini diduga karena stasiun ini berada di area pelabuhan. Perairan di sekitar kawasan pelabuhan menerima limbah serara terus menerus dari aktivitas rutin dan pengisian bahan bakar kapal, serta dipengaruhi oleh 
ceceran minyak dari kapal-kapal yang berlabuh.

Tumpahan minyak akan membuat sebuah lapisan pada permukaan perairan, hal ini akan memberi pengaruh kepada terhambatnya penetrasi cahaya matahari ke dalam perairan, sehingga akan mengganggu proses fotosintesis diatom, akibatnya kelimpahan diatom akan berkurang. Hal ini sesuai dengan yang dikemukan oleh [23], menyatakan bahwa limbah yang berasal dari kapal mengandung minyak yang berasal dari tangki bahan bakar dan minyak merupakan polutan yang berpotensi mencemari laut. Lapisan minyak yang ada di permukaan air akan menghalangi masuknya sinar matahari ke dalam air sehingga proses fotosintesis oleh tanaman air menjadi terganggu. Akibatnya, oksigen yang seharusnya dihasilkan pada proses fotosintesis tersebut tidak terjadi dan kandungan oksigen dalam air menjadi menurun.

Lapisan minyak pada permukaan air juga akan menghalangi difusi oksigen dari udara ke dalam air sehingga jumlah oksigen yang terlarut di dalam air menjadi semakin berkurang. Kandungan oksigen yang menurun akan mengganggu kehidupan hewan air. Hal ini menunjukkan bahwa adanya minyak pada perairan akan menurunkan kualitas perairan dan mempengaruhi kehidupan organisme di perairan tersebut termasuk diatom [24].

Hasil uji anova satu arah untuk kelimpahan diatom diperoleh nilai signifikasi yaitu 0,028 sehingga $\mathrm{P}<0,05$ yang menandakan kelimpahan diatom antar stasiun penelitian berbeda nyata.

\section{Pengaruh Kandungan Nitrat, Fosfat dan Silikat Terhadap Kelimpahan Diatom Planktonik}

Berdasarkan hasil analisis linier berganda didapat nilai koefisien korelasi (r) dengan nilai 0,633 menujukkan bahwa pengaruh antara kandungan nitrat, fosfat dan silikat terhadap kelimpahan diatom adalah kuat. Kemudian nilai $\mathrm{R}$ square $\left(\mathrm{R}^{2}\right)$ bernilai 0,401 artinya persentasi sumbangan dari variabel nitrat, fosfat dan silikat terhadap diatom adalah $40,1 \%$ dan sisanya 59,9 \% dipengaruhi oleh faktor lain. Selanjutnya diperoleh persamaan regresi linier berganda sebagai berikut:

$$
\begin{aligned}
& Y=743,019-481,828_{\text {Nitrat }}-199,552_{\text {Fosfat }} \\
& -172,971_{\text {Silikat }}
\end{aligned}
$$

Hasil persamaan analisis linier berganda menunjukkan bahwa pengaruh kandungan nitrat, fosfat dan silikat terhadap kelimpahan diatom memiliki hubungan negatif. Berdasarkan hasil perhitungan pada analisis regresi linier berganda diketahui bahwa adanya hubungan negatif antara variabel nitrat terhadap kelimpahan diatom dengan nilai koefisien nitrat yaitu $-481,828$ dengan nilai determinasi $\left(\mathrm{R}^{2}\right)=0,401$ dan nilai korelasi $r=0,633$. Nitrat memberikan pengaruh terhadap kelimpahan diatom sebesar $-4,818 \%$ dengan nilai negatif, yang mana semakin tinggi kandungan nitrat, maka kelimpahan diatom di Perairan Muara Sungai Batang Arau akan menurun.

Kandungan nitrat di perairan ini sudah berada di atas standar baku mutu. Baku mutu kandungan nitrat yang layak untuk kehidupan biota laut dalam Keputusan Mentri Lingkungan Hidup, KLH tahun 2004 adalah 0,008 mg/l. Data hasil penelitian menunjukkan bahwa kandungan nitrat di perairan ini berada di batas yang di persyaratkan, ini dapat menjadi faktor penghambat bagi pertumbuhan dan perkembangan diatom di perairan. Hal ini sesuai dengan pernyataan [25] menyatakan, nitrat merupakan nutrisi utama yang di butuhkan oleh diatom untuk tumbuh dan berkembang dengan baik, besarnya kandungan nitrat yang ada pada perairan akan merangsang pertumbuhan bagi diatom, karena nitrat pada kandungan tertentu dapat memberikan kondisi pertumbuhan baik bagi diatom dan dapat 
menjadi racun di perairan apabila kandungan melebihi yang dibutuhkan.

Beberapa jenis fitoplankton seperti diatom hanya mampu memanfaatkan nitrogen dari unsur sederhana seperti nitrat dan jenis lainnya mampu menyerap nitrogen dari unsur yang lebih kompleks seperti ammonia dan. Sebaliknya, konsentrasi amonium tinggi akan menghambat atau mengurangi penyerapan nitrat oleh beberapa jenis fitoplankton sehingga menghasilkan perkembangan fitoplankton yang menurun [27].

Berdasarkan hasil perhitungan pada analisis regresi linier berganda diketahui bahwa adanya hubungan negatif antara variabel fosfat terhadap kelimpahan diatom dengan nilai koefisien fosfat yaitu $-199,552$ dengan nilai determinasi $\left(\mathrm{R}^{2}\right)=0,401$ dan nilai korelasi $r=0,633$. Fosfat memberikan pengaruh terhadap kelimpahan diatom sebesar $-1,995 \%$ dengan nilai negatif, yang artinya semakin tinggi kandungan fosfat, maka kelimpahan diatom di Perairan Muara Sungai Batang Arau akan menurun.

Menurut [28] bahwa tingginya kandungan fosfat disebabkan pemanfaatan fosfat oleh diatom kurang optimal yang dapat dilihat dengan rendahnya kelimpahan diatom. Meningkatnya populasi fitoplankton dapat menurunkan kadar fosfat dalam suatu perairan. Hal ini sesuai dengan apa yang dikatakan [29] bahwa adanya peningkatan kandungan fosfat diduga memberikan pengaruh terhadap kelimpahan diatom.

Berdasarkan hasil perhitungan pada analisis regresi linier berganda diketahui bahwa adanya hubungan negatif antara variabel silikat terhadap kelimpahan diatom dengan nilai koefisien silikat yaitu $-172,971$ dengan nilai determinasi $\left(\mathrm{R}^{2}\right)=0,401$ dan nilai korelasi $r=0,633$. Silikat memberikan pengaruh terhadap kelimpahan diatom sebesar $-1,729 \%$ dengan nilai negatif, yang artinya semakin tinggi kandungan silikat, maka kelimpahan diatom di Perairan Muara Sungai Batang Arau akan menurun.
[16] menyatakan bahwa silika sangat dibutuhkan untuk pembentukan dinding sel pada diatom dan hal tersebut tergantung pada tersedianya silika yang terlarut pada sebuah perairan. Hal ini sesuai dengan pernyataan [17], bahwa nutrien silikat diperlukan dan berpengaruh terhadap proses pertumbuhan dan perkembangan hidup beberapa jenis fitoplankton diantaranya diatom untuk pembentukan kerangka dinding selnya. Namun adakalanya silikat bisa menjadi faktor pembatas bagi pertumbuhan fitoplankton khususnya diatom, walaupun peran tersebut masih ditentukan oleh nutrien utama yaitu nitrogen dan fosfor [30].

\section{KESIMPULAN DAN SARAN}

Kandungan nitrat berkisar antara 0,117-0,485 mg/l, fosfat 0,239-0,704 mg/l, dan silikat 0,031-0,685 mg/l. Kelimpahan diatom planktonik berkisar antara 194,444750,000 ind/l. Diatom planktonik yang ditemui yaitu sebanyak 20 spesies, dimana 9 spesies tergolong ke dalam tipe diatom Centrales dan 11 spesies diatom lainnya tergolong ke dalam diatom tipe Pennales.

Kandungan nitrat, fosfat, silikat dan diatom antar stasiun penelitian berbeda nyata. Pengaruh antara kandungan nitrat, fosfat dan silikat terhadap kelimpahan diatom adalah kuat dengan nilai negatif, semakin meningkat kandungan nitrat, fosfat dan silikat maka kelimpahan diatom akan semakin menurun. Pengaruh nitrat, fosfat dan silikat terhadap kelimpahan diatom adalah $40,1 \%$ dan sisanya $59,9 \%$ dipengaruhi oleh faktor lain.

Pada penelitian ini analisis yang dilakukan hanya pengaruh kandungan nitrat, fosfat dan silikat terhadap kelimpahan diatom planktonik, maka perlu dilakukan penelitian lebih lanjut mengenai kandungan minyak, dikarenakan banyaknya kegiatan perkapalan yang menimbulkan pencemaran berupa minyak, sehingga dapat menganggu ekosistem perairan tersebut terutama diatom planktonik. 


\section{DAFTAR PUSTAKA}

1. Ulqodry, T.Z. (2010). Karakterisitik dan Sebaran Nitrat, Fosfat, dan Oksigen Terlarut di Perairan Karimun Jawa Jawa Tengah. Jurnal Penelitian Sains, 13(1): 13- 109.

2. Samiaji, J. (2015). Planktonologi Laut. Bahan Ajar Perkuliahan Planktonologi Laut Jurusan Ilmu Kelautan Fakultas Perikanan dan Ilmu Kelautan Universitas Riau.

3. [APHA] American Public Health Association. (1989). Standard methods for the Examination of Water and Waste Water. American Public Health Association (APHA). American Water Works Association (AWWA) and Water Pollution Control Federation (WPCF). 17th ed. Washington. $1193 \mathrm{hlm}$.

4. Yamaji, I. (1976). Illustration of The Marine Plankton of Japan $8^{\text {th }}$ Ed. Hoikhusa Publissing Co. Ltd. Tokyo. 563 P.

5. [APHA] American Public Health Association. (1995). Standard Methods for The Examination of Water and Wastewater. $\left(19^{\text {th }} \mathrm{ed}\right)$. American Water Works Association, Water Pollution Control Federation. Washington D.C.

6. [DLH]. Dinas Lingkungan Hidup. (2017) Laporan Pengelolaan Lingkungan Hidup Kota Padang. Dinas Lingkungan Hidup Kota Padang; 2017.

7. Muchtar, M. (2012). Distribusi Zat Hara Fosfat, Nitrat dan Silikat di Perairan Kepulauan Natuna. Jurnal Ilmu dan Teknologi Kelautan Tropis, 4(2): 304-317

8. Amin. M., S. Nedi, dan I. Nurrachmi. (2017). Analisis Tingkat Kesuburan Perairan Muara Sungai Mesjid Kota Dumai Ditinjau dari Nitrat, Fosfat dan Kelimpahan Diatom. Jurnal Online Mahasiswa Fakultas Perikanan dan Kelautan Universitas Riau

9. Hidayat, R., S. Nedi, dan I. Nurrachmi. (2019). Analysis Concentration of Nitrate, Phosphate, Silicate and Relationship with Diatom Abudance in Water Tanjung Tiram District Batubara Regency of North Suamtera Province. Asian Journal of Aquatic Science, 2(1): 1-11

10. Muchtar. (2001). Distribusi Beberapa Parameter Kimia di Perairan Muara Sungai Digul dan Arafura, Irian Jaya. Oseanologi-LIPI.

11. Makmur, M., H. Kusnoputranto, S.S. Moersidik dan S.D. Wisnubroto. (2012). Pengaruh Limbah Organik dan Rasio N/P Terhadap Kelimpahan Fitoplankton di Kawasan Budidaya Kerang Hijau Cilincing. BATAN.

12. Simanjuntak, M. (2006). Kadar Fosfat, Nitrat dan Silikat Kaitannya dengan Kesuburan Perairan Delta Mahakam, Kalimantan Timur. Pusat Penelitian Oseanografi Lipi. Jakarta

13. Tarigan, D.A., M. Yusuf dan M. Lilik. (2014). Sebaran Nitrat dan Fosfat di Perairan Muara Sungai Porong Kabupaten Sidoarjo. Jurnal Oseanografi, 3(3): 384 - 391

14. Patty, S.I. (2014). Kadar Fosfat, Nitrat dan Oksigen Terlarut di Perairan Pulau Talise, Sulawesi Utara. Jurnal Ilmiah Platak, 1(4) : 167-176.

15. Simanjuntak, M. (2013). Kualitas perairan Gresik, Jawa Timur: Kandungan Nutrien, Oksigen Terlarut dan Derajat Keasaman. Jurnal Oseanologi dan Limnologi, 39(2): 125262.

16. Risamasu, F.J.L. dan H.B. Prayitno. (2011). Kajian Zat Hara Fosfat, Nitrit, Nitrat dan Silikat di Perairan Kepulauan Matasiri, Kalimantan Selatan. Jurnal Ilmu Kelautan, 16(3):135-142. 
17. Simanjuntak, M. (2012). Kualitas Air Laut Ditinjau dari Aspek Zat Hara, Oksigen Terlarut dan pH Di Perairan Banggai, Sulawesi Tengah. Jurnal Ilmu dan Teknologi Kelautan Tropis, IV (2): 290-303.

18. Nontji, A. (2008). Plankton Laut. LIPI press. Jakarta. $331 \mathrm{hlm}$.

19. Siregar, S.H., A. Mulyadi dan O.J. Hasibuan. (2008). Struktur Diatom Epilitik (Bacillariophyceae) pada Lambung Kapal di Perairan Dumai Provinsi Riau. Journal of environmental Science, 2(2)

20. Romimohtarto, K. dan S. Juwana. (2001). Biologi Laut Ilmu Pengetahuan tentang Biota Laut. Jakarta: Djambatan.

21. Effendi, H. (2003). Telaah Kualitas Air Bagi Pengelolaan Sumber Daya dan Lingkungan Perairan. Penerbit Kanisius. Yogyakarta.

22. Suparjo, M.N. (2009). Kondisi Pencemaran Perairan Sungai Babon Semarang. Manajemen Sumberdaya Peariran. Perikanan. Universitas Diponegoro. Semarang

23. Mukhtasor. (2007). Pencemaran Pesisir dan Laut. PT. Pradnya Paramita. Jakarta. 159 hlm.

24. Wardhana, W.A. (2004). Dampak Pencemaran Lingkungan. Edisi Revisi. Andi. Yogyakarta. $462 \mathrm{hlm}$

25. Permatasari, R.D., D. Djuwito dan I. Irwani. (2016). Pengaruh Kandungan Nitrat dan Fosfat terhadap Kelimpahan Diatom di Muara Sungai Wulan, Demak. Management of Aquatic Resources Journa, 5(4): 224-232.

26. Patey, M.D., M.J.A. Rijkenberg, P.J. Statham, M.C. Stinchcombe, E.P. Achterberg dan M. Mowlem. (2008). Determination of Nitrate and Phosphate in Sea Water at Nano Molar Concentration. Trends in Analytical Chemistry, 27 (2): 169-182

27. Tan, K.S. dan J. Ransangan. (2017). Effects of nutrients and zooplankton on the phytoplankton community structure in Marudu Bay. Estuarine, Coastal and Shelf Science 194: 16-29.

28. Hasrun. L., K. Ma'ruf dan Salwiyah. (2013). Studi Biodiversitas Diatom Bentik pada Areal Manggrove di Perairan Kecamatan Kolono Kabupaten Konawe Selatan. Jurnal Mina Laut Indonesia, 2(6): 35-47.

29. Widianingsih, K.S., R. Hartati dan S.Y. Wulandari. (2011). Komposisi Jenis dan Kelimpahan Diatom Benthik di Muara Sungai Comal Baru Pemalang. Ilmu Kelautan: Indonesian Journal of Marine Sciences, 16 (1) 16 - 23.

30. Zhang, J., M.S. Liu, Y. Wu, H.X. Qi, S.G. Zhang, and X.R. Li. (2006). Dissolved silica in the Changjiang (Yangtze River) and adjacent coastal waters of the East China Sea. In: Ittekkot, V., D. Unger, C. Humborg, and N.T. An (eds.) The Silicon Cycle,. Washington, Island Press.71-80pp. 